\title{
REMAKING THE HERITAGE OF THE ITALIAN CONCENTRATION CAMP ON THE ISLAND OF RAB
}

\section{BOŽIDAR JEZERNIK}

The article deals with the political and military organization of the former internees in the Italian concentration camp Rab. Although there were only about 2,000 of them at the beginning of September 1943, they managed to disarm the entire Italian military garrison on the island of Rab, which consisted of 2,200 soldiers and carabinieri, partly by cunning and partly by force. It was a unique event in world history, made even more glorious by the fact that no Italian soldiers or carabinieri were liquidated in the process. The head of the Executive Committee of the clandestine Liberation Front was Jože Jurančič, who was arrested in 1949 and then imprisoned on Goli Otok. As such, he was one of the former internees of the Rab concentration camp who carved stones and placed them in the renovated cemetery of the former internees of Rab.

Keywords: Jože Jurančič, Rab concentration camp, disarmament of the Italian garrison on the island of Rab, Rab Brigade, Edvard Ravnikar, memorial complex Kampor, Goli otok concentration camp
Članek obravnava politično in vojaško organiziranost nekdanjih internirancev $v$ italijanskem koncentracijskem taborišcu Rab. Čeprav jih je bilo tam v začetku meseca septembra 1943 le še kakih 2000, pa so deloma z zvijačo, deloma s silo uspeli razorožiti celotno italijansko vojaško posadko na otoku Rab, kije štela 2200 vojakov in karabinjerjev. To je bil enkraten dogodek v svetovni zgodovini, še dodatno pa ga poveličuje dejstvo, da ob tem ni bil likvidiran noben italijanski vojak ali karabinjer. Vodja taborišcne organizacije OF je bil Jože Jurančič, ki je bil leta 1949 aretiran in nato zaprt na Golem otoku. Bil je eden od golootoških internirancev, ki so klesali kamen, postavljen na prenovljenem pokopališcu nekdanjih rabskih internirancev.

Ključne besede: Jože Jurančič, Rab concentration camp, disarmament of the Italian garrison on the island of Rab, Rab Brigade, Edvard Ravnikar, memorial complex Kampor, Goli otok concentration camp

The past is partly a product of the present, asserts David Lowenthal, as we continually reshape memory, rewrite history, refashion relics (Lowenthal, 1985: 26). Every act of recognition alters relics of the past, Lowenthal argues, adding that the mere appreciation or protection of a relic, let alone its embellishment or imitation, affects its form or our impressions. Therefore, interaction with a heritage continually alters its nature and context, whether by choice or by chance (ibid.: 263).

This is also true of the Memorial Complex in Kampor Bay, built in 1953 on the former cemetery of the more than a thousand victims of the Italian concentration camp on the island of Rab. After the end of the Second World War, the Memorial Complex was built there as a result of a double denial. On the one hand, Jože Jurančič, the heroic leader of one of the greatest heroic endeavors in Slovenian history, was suppressed from social memory, and on the other, the victims of the Italian concentration camp buried there were deprived of their individual graves. 


\section{RAB CONCENTRACION CAMP}

The persecution of the population of the Province of Ljubljana reached its climax at the end of June, in July, and in early August 1942, when plans were made to shoot anyone in any way connected with the resistance during the offensive (in practice, this meant that Italian soldiers shot men they encountered outside their place of residence; the same fate befell Partisans who surrendered unarmed to Italian authorities), houses and villages whose inhabitants were connected to the resistance movement were burned, and thousands of civilians were interned (Jezernik, 1999: 22). The military units that carried out these "appeasement" operations had explicit orders not to consider the "guilt" of persons from the categories designated for closer investigation, either individually or in general. At a meeting of the Command of the XI Army Corps on June 20, 1942, it was even envisaged that during the purges "a few guilty, many innocent, many partially implicated" would be captured. ${ }^{1}$ According to the official documents of the Italian government, at the end of October 1942, there were "about 20,000 Slovenian civilian internees" in five concentration camps (Rab, Padua, Treviso, Gonars, and Renicci). ${ }^{2}$

The raids continued at intervals until the end of September 1942 and, to a lesser extent, until February 1943. The Commission for the Investigation of the Crimes of the Italian Occupiers and its Collaborators in the Province of Ljubljana documented 42 such raids from June 28, 1942, to February 7, 1943. ${ }^{3}$ Raids in the Province of Fiume were not recorded, although the Italian authorities there also used severe violence against the civilian population in the summer of 1942 (see, e.g., Malnar, 2003: 7-8). According to the data collected by Zdravko Troha, at the end of March 1942, there were 12,263 inhabitants in the Čabar district, in the municipalities of Črni lug, Čabar, Gerovo, Plašče, Prezid, Draga, and Osilnica, and by the end of September, there were only $5,545 .^{4}$

Although the so-called Communists were the main target of the Italian authorities, the mass raids in Ljubljana in June 1942 and during the so-called Rog offensive arrested more people "who had no connections with Communism" than Communists. An anonymous author of a report for the office of the Village Guard in Ljubljana wrote about the events in Ljubljana in the last days of June 1942. In his report, he wrote that the Italian authorities had arrested "at least" two-thirds of the Catholic students, men and boys. In his opinion,

1 »Komisija za ugotavljanje zločinov okupatorjev in njihovih pomagačev za Slovenijo" in »Inštitut narodne osvoboditve pri predsedstvu vlade LRS«. 1946. Zločini italijanskega okupatorja v "Ljubljanski pokrajini«, vol. 1: Internacije, doc. nos. 27 and 19. Ljubljana.

2 Presidenza consiglio dei ministri. 1942/43. Sistemazione internati civili sloveni. Archivio centrale dello stato Roma, Presidenza del Consiglio dei Ministri 1940-43, map 3177, folder 29, doc. no. 7368.

3 „Komisija za ugotavljanje zločinov okupatorjev in njihovih pomagačev za Slovenijo« in "Inštitut narodne osvoboditve pri predsedstvu vlade LRS«, ibid., 18-19.

4 Troha, Zdravko. 1996. Personal information.

5 Šeškar, France. 1942. G. Pregelj!; Kostanjevica, 14. oktobra 1942. Arhcive of the Inštitut za novejšo zgodovino Ljubljana, Domobranski fondi, folder 120, Situacijska poročila pisarni M7 iz raznih krajev pokrajine. 
this meant that those "who were outstandingly active in the struggle against Communism and the Liberation Front" were interned, "while many criminal types and undisputed supporters of Communism and the Liberation Front remained free."

On July 27, 1942, the first group of 170 internees was transported to the Rab concentration camp, and further transports followed till the beginning of October 1942. In his letter from December 16, 1942, the commander of the Second Army, General Mario Roatta, admitted that the highest daily number of internees was 10,552 (Walston, 1997: 176). About two-thirds of the new inhabitants of the Rab concentration camp came from Notranjska, Dolenjska, and Bela Krajina, others from the Province of Fiume. Among the internees from the Province of Ljubljana, men predominated, while among the internees from the Province of Fiume one could find all categories, from pregnant women and babies to old men and women (Jezernik, 1999: 37).

By the time the first transports arrived, some forty guardhouses, barbed wire, and many low tents had been erected. The first internees had to erect the rest of the tents themselves until a whole town of low tents had been formed. The construction of buildings of wood and stone began in August 1942 and continued until the concentration camp was closed. Construction dragged on so much that the low tents were not dismantled until mid-January 1943. They were replaced by wooden huts and large tents for twenty people with an iron frame, wooden floors, and wooden bunks. The construction of the Rab concentration camp lasted almost until its dissolution in September 1943. The only unit completed was the cemetery or "Fifth Sector," i.e. the cemetery for internees (Badurina, 1942; Potočnik, 1951: 39, 1975: 84-85; Pakiž, 1953: 68; Vratuša, 1998: 58).

Living conditions for the inmates on Rab were generally harsher than in other Italian concentration camps, resulting in extremely high mortality in November and December 1942. Children and the elderly were particularly badly affected. According to the Monastery Chronicle, the first victim was Vilim Malner, born on May 22, 1942, in Srager near Čabar (died on August 5, 1942). Dying in large numbers continued until the end of January 1943. The suspended parish priest from Ig and Rab, internee Filip Marješič, wrote a lengthy poem, numerous copies of which circulated among the Slovenian internees. It begins as follows:

\section{Otok Arbe - letovišče, kras Jadranskega morja, zdaj postalo si grobišče naroda slovenskega. \\ Tu so zbrani vsi stanovi: radnik, kmet in advokat, tu so naši že grobovi - kje je naša blagodat?}

(Bojc, 1974: 189)

6 Poročilo o dogodkih v Ljubljani zadnje dni junija 1942. Archive of the Inštitut za novejšo zgodovino Ljubljana, Domobranski fondi, folder 120, Situacijska poročila pisarni M7 iz raznih krajev pokrajine.

7 The island of Arbe - a resort, / a jewel of the Adriatic Sea, / Has now become a cemetery of the Slovenian nation. / All walks of life are represented here: the worker, the peasant, and the lawyer, / Here are already our graves - where is our grace? 


\section{THE PERSECUTED TEACHER}

Among the internees in the Rab concentration camp was Jože Jurančič. Jurančič was "connected" by the writer Prežihov Voranc with the illegal Communist Party of Yugoslavia on May 1, 1925 (Škufca, 1998: 17; Smole, 2002: 37). His Communist ideology was marked by an enlightened will to uplift the proletarian and rural masses. The needs of the people led him to deviate his activities from their regular didactic course, meaning that he did not simply follow the curriculum when teaching, but rather life as he saw it. He built on the needs of the people with the intention of awakening their "sleeping powers" and breaking with their economic, social, cultural, and spiritual decay. In his own words, he strove to challenge the circumstances that stood in the way of progress and to create an environment that would help "sharpen the minds of the people so that they can distinguish healthy from unhealthy, beauty from ugliness, just from unjust" (Jurančič, 1930: 5-6). State authorities in the Kingdom of Yugoslavia were not in favor of Communism, especially in schools; they urged the country's educational institutions to "consider Communism strictly an evil" (Nikolić, 1994: 95). Committed teacher-communists were either forcibly retired or transferred to remote schools as punishment. The teacher Jurančič suffered from the long hand of the state several times. His professional path led him from Markovci near Ptuj to Slovenj Gradec, from there to Remšnik in Kobansko, then back to Markovci, from where, together with his wife Leopoldina, he was transferred as punishment to Telče near Tržišče in Dolenjsko, a remote mountain village where "many a teacher had drunk himself to death" (Strmčnik, 1999: 350; Smole, 2002: 38). He ended his teaching career in Šmarjeta on Dolenjska, where he and his wife Leopoldina moved on January 1, 1942 (Smole, 2002: 39). There, too, Jurančič's imperative to promote knowledge and the emancipation of the people quickly caught on. According to the commendable assessment of the historian Stane Granda, Jože Jurančič was indeed a Communist, but one "driven by a sense of social justice and just class relations, not by a lust for power" (Granda, 2007: 149).

Because of his activity in the organization of the national liberation movement in Dolenjsko, he was arrested on April 16, 1942 (Smole, 2002: 39). In Novo Mesto prison, he was among the hostages waiting to be executed for reprisals against the insurgent population. As his son Igor Jurančič recalls, the priest Ignacij Škoda rescued him from there, albeit unintentionally. Škoda visited the Novo Mesto prison several times and urged the prison authorities to shoot the Communist Jurančič. The Italian officer, the commander of the unit, replied, "We will shoot whoever we want, and whether we do it or not is for us to say, not you!" The priest left indignantly a few minutes later, and the commander immediately crossed Jurančič off the list of hostages and entered him into the list for the Rab concentration camp. ${ }^{8}$ Thus, on September 7, 1942, Jurančič arrived on the island of Rab as an internee via the prisons in Novo Mesto and Ljubljana. His wife Leopoldina Jurančič,

8 Jurančič, Igor. 2021. Oral information. 
district secretary of the Liberation Front, was the first female hostage in Dolenjsko, executed three weeks later by firing squad; the hostages were forced to dig their own graves. The couple's children were left to fend for themselves (Beretič, 1985: 19; Jurančič, 1985: 100; Škufca, 1998: 17; Smole, 2002: 39).

Jurančič maintained an awareness of his "duty" even in the chaotic circumstances of life in extremis at the end of 1942. In the mass of strangers, he used his "unconscious instinct" to look for fellow communists, and as early as September 1942, he drafted a clandestine Communist Party committee of which he was secretary. Its members stirred up the morale of the internees, which for the most part was rapidly faltering because of great hunger and fear, to revive a sense of community that had all but evaporated in the struggle for bare survival (see, e.g., Malnar, 2003: 21-22). Former internees recalled that Jurančič "forcibly pulled the depressed and starving out from under their tents so that they would not fall asleep for good" (Smole, 2002: 39). All the while, he and his comrades were searching for "reliable men" to recruit them for political activity "on a broad scale" (Potočnik, 1975: 177-178; Jurančič, 1985: 96-97; Vratuša, 1998: 113-114). Under the given conditions, political work consisted largely of convincing fellow inmates that they were imprisoned in the concentration camp because

we are Slovenians, because we long for freedom, because we want to be masters in our own house. The Nazis and Fascists occupied our homeland with a clear goal: to murder some, to denationalize others, to deport and resettle the people in order to eradicate us from our land, a part of Europe that the Italians and Germans have coveted for centuries. We resisted the gloom we encountered, one that fell on the inmates in the brutal camp violence: the resistance was broken, the Partisans decimated, captured, and the Liberation Front worn down-and countered with our own narrative that the Partisan army was growing and even retaliating against the occupiers, who were already retreating from their outposts to the great strongholds. (Potočnik, 1975: 176-177)

\section{THE LIBERATION FRONT IN THE CONCENTRATION CAMP}

The defeat of the German army at Stalingrad triggered a massive change in the political mood of the inmates. As early as January 5, 1943, they formed a Liberation Front Executive Committee as their central leadership; Jurančič was elected secretary. By April 1943, the illegal organization of the Liberation Front in Camp I already numbered over 400 members (Potočnik, 1975: 182). In the Rab concentration camp, in addition to Slovenians, there were also Croats and later Jewish internees, yet a unified political and military organization applied to all (ibid.: 183), as there was only one line of distinction: "anti-Fascist Yugoslav patriots on one side, and on the other, the invader's spies." They had a common enemy-Fascist 
occupiers,"-and a common goal-liberation. The common enemy and the common goal were such a powerful unifying force that homogeneous political and military integration was never questionable. "Perhaps there were even more differences between the inmates from Ribnica and Notranjska," Franci Drenovec recalls, "than between the Slovenians and the Croats" (Drenovec, 1953: 122).

Despite being separated by a barbed wire, the CPY committees in the Slovenian and Jewish camps (Camp I and II) managed to establish connections and cooperation. To coordinate the activities and organization of the Osvobodilna fronta (Liberation Front) in the Slovenian camp with the National Liberation Committee in the Jewish one, a joint OF Executive Committee was formed; the secretary was Jože Jurančič, his Jewish counterpart Viktor Hajon. The joint committee of the camps consisted of the same members as the joint committee of the Communist Party of Yugoslavia, which made coordination between the four underground prisoner groups easier (Romano, 1973: 23-24; 1980: 293).

The OF Executive Committee felt that camp inmates were in "constant danger of being liquidated." For this reason, they formed a military unit that would act as a "shock troop of resistance around which the other internees could rally in the event of mortal danger" (Potočnik, 1953c: 145). This designated Strike Battalion had four companies, consisting of ten patrols with four fighters each. In addition, the internees also established a Military Police detachment of thirty men so that the combat duties of the Strike Battalion would not mix with intelligence activities; this was seen as crucial for the potentially decisive moment when "enemy elements" would be arrested and placed under guard (ibid.: 146, 148).

On September 8, 1943, enthusiasm spread like wildfire among Italian soldiers and carabinieri. Soldiers abandoned their posts, noted Odoriko Badurina, tossing hats in the air and rifles on the ground, celebrating loudly, "Andiamo à casa!" (“We're going home!”). The Executive Committee of the OF declared that "the official capitulation of Italy" meant the annulment of the annexation of the Province of Ljubljana and the immediate end of the internment. They appointed a delegation to meet with Vincenzo Cujuli, lieutenant colonel of the carabinieri and commander of the Italian military garrison on the island of Rab, to inform him that the internees were declaring themselves free citizens. Nevertheless, they decided to remain in the camp voluntarily for the immediate future, and would publicly vote on their "self-government" at a general meeting scheduled for the next day. Commander Cujuli was invited to attend (Potočnik, 1946: 14, 1951: 49, 1975: 203).

The general meeting of the Rab concentration camp inmates took place on September 10, 1943. At ten o'clock in the morning, rows of Slovenian, Croat, and Jewish inmates assembled in a solemn mood around the makeshift podium in the middle of Trg Lakote ("Hunger Square"), which was decorated with a large Slovenian five-pointed star flag. A number of Italian soldiers and carabinieri arrived, including Commander Cujuli, armed to the teeth and escorted by helmeted officers. From the lectern, Jurančič greeted them with a raised fist: "Death to Fascism!", to which the inmates thunderously answered with "Freedom to the people!" The surprised Cujuli and his officers saluted. Jurančič expressed 
satisfaction that Italy had entered the circle of the Allies, "fighting for the same goals for which the internees had suffered in the concentration camp." In the following, he described the situation to the Italians and introduced members of the Liberation Front Executive Committee. The assembly cheered and staged a "democratic election" to appoint new members and approve various commissions. The OF Executive Committee thus "assumed power in the former concentration camp." On the spot, the decision was confirmed to create a military unit in the strength of a brigade on a completely voluntary basis, and to elect Franc Potočnik as its commander and Jože Jurančič as its political commissary (Jurančič, 1944: 48; Potočnik, 1948: 473, 1951: 50, 1975: 206-207).

Jurančič was followed by other speakers who called on those present to liberate the camp. The crowd roared at the roll call, waved flags and sang, shouted in Italian that peace would last long and that the war would finally be over, cheered the Badoglio government and chanted slogans of freedom as they marched towards the guardhouse at the camp entrance. Some Italian soldiers were already handing over their rifles to women in the peace procession, and the camp guards also surrendered their weapons without resistance. They were replaced at their former posts by armed ex-internees (Romano, 1973: 27-28; 1980: 293; Potočnik, 1975: 211; Vratuša, 1998: 183-184).

\section{DISARMING THE ITALIAN SOLDIERS AND THE CARABINIERI}

On September 9, 1943, the delegation from OF had approached Commander Cujuli with the demand that now that Italy had gone over to the side of the Allies, they should be given arms and the right to govern themselves. Cujuli allowed them to organize the meeting but refused to supply arms for the time being. Later in the day, he relented somewhat and gave them some rifles to "guard the camp." At the meeting, the former internees then demanded half of the camp's weapons, "for the common defense" against the Ustashi and the Germans. ${ }^{9}$ On the afternoon of September 11, 1943, Garrison Lieutenant Nanni summoned representatives of the former internees to officially hand over power over the camp. Jože Jurančič attended the meeting with an armed escort, and they were received by several Italian officers. In front of the concentration camp administration building, an Italian soldier blew to lower the flag. Those present saluted the Italian colors before the Slovenian five-pointed star flag ${ }^{10}$ was ceremoniously hoisted on the pole. When the flag change was completed, the Italian officers and guards present laid down their weapons and left the camp: the inmates were officially in charge. This symbolic gesture had made the disarmament of the Italian garrison still stationed on the site "much easier" and "undoubtedly

9 Poročilo IOOF internirancem. Rab, 10. september 1943 ob 3. popoldne. Archive of the Inštitut za zgodovino delavskega gibanja, collection Rab.

10 Franc Potočnik stated in 1946 that it was a Yugoslav flag (Potočnik, 1946: 14), but two years later corrected his memory and wrote that it was "a Slovenian flag with a red star" (Potočnik, 1948: 473). 
prevented many incidents that could have occurred in the process" (Jurančič, 1944: 46; Potočnik, 1946: 14, 1948: 473, 1975: 212-213; Konjhodžić, 1963: 556).

On September 11, 1943, the Italian soldiers began moving to the town of Rab to board ships. On their way to the port they were intercepted, their rifles confiscated, partly by trickery, partly by force, by militarized units of former internees who then did the same to those already on board. Thus, without a single bullet fired, the weapons of the entire Italian military garrison at the Rab Island, which amounted to some 2000 rifles, 15 machine guns, and six cannons, fell into the hands of the Liberation Front (Potočnik, 1953c: 156, 1975: 208-211, 215; Romano, 1973: 28-29). The disarmed Italian soldiers and the carabinieri, finding themselves without leadership, dispersed indiscriminately: some sailed north, towards Fiume/Rijeka or Trieste, others tried to reach Italy by improvised means. It is recorded that many were stopped by the Germans and ended up in the concentration camps of the Third Reich. There were also those who set off into the mountains to join the Yugoslav partisans ${ }^{11}$ (Grazia, 2010: 12).

The military garrison on the Rab Island included about 2200 armed and trained soldiers and carabinieri. The internees initially had at their disposal only two rifles and about twenty grenades, which they received that day from the National Liberation Committee on the island of Rab and from emissaries of the National Liberation Army who had arrived on the island (Potočnik, 1946: 14, 1953c: 154). In itself, the disarmament of such an unequal force was an achievement without historical parallel, and, certainly, no greater deed is known in the Slovenian past. Moreover, the ex-internees did not execute a single Italian soldier during or after its course-undoubtedly not for lack of desire for revenge, as many would have gladly taken justice into their own hands (Vratuša, 1998: 181-182). That no revenge took place is to the credit of the OF Executive Committee. In its first public pronouncement, proclaiming itself the sole legal representative of "our national authority," the Executive Committee strictly forbade "any personal retaliation or private revenge." It even threatened that failure to comply with it "will be considered disobedience to the Executive Committee and will have ... (harmf)ull consequences." 12 It stated this despite the family tragedy of the secretary of the OF Executive Committee.

On September 10, 1943, the OF Executive Committee ordered the arrest of "informers, black marketeers, and other anti-social elements" in the concentration camp: Jurca, Umek, Wizinger, Remec, and Klepec. ${ }^{13}$ These were brought before the so-called Brigade or People's Tribunal chaired by judge Silverij Pakiž. The Tribunal ruled that Lieutenant Colonel Vincenzo Cujuli was "indisputably guilty" of committing crimes against the inmates of the Rab concentration camp and sentenced him to death. A death sentence

11 Giancarlo Grazia. 2010. Il campo della morte: L'isola di Arbe. Patria Indipendente, November 28: 12.

12 Proglas. Rab, 10. september 1943. Archive of the Inštitut za novejšo zgodovino Ljubljana, Collection Rab.

13 Poročilo IO internirancem. Rab, 10. september 1943 ob 21,00. Archive of the Inštitut za novejšo zgodovino, collection Rab. 


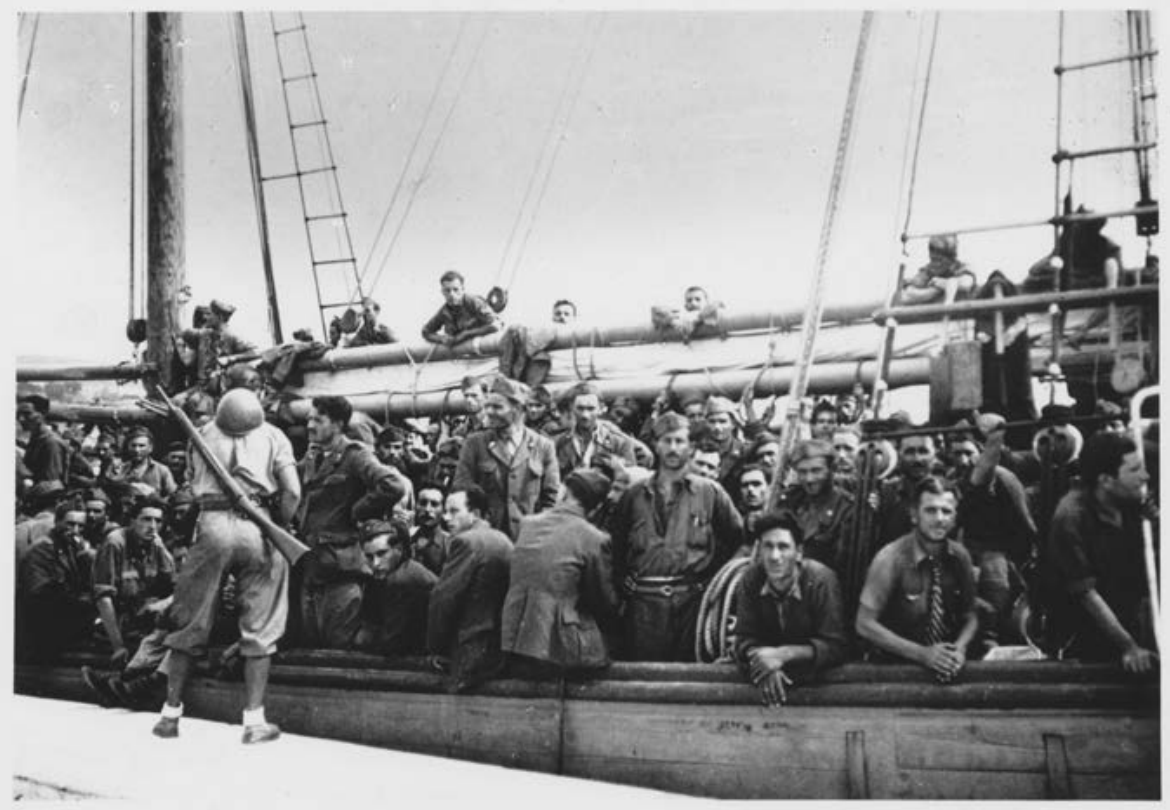

Figure 1. Disarmed Italian soldiers leaving the island of Rab, September 1943.

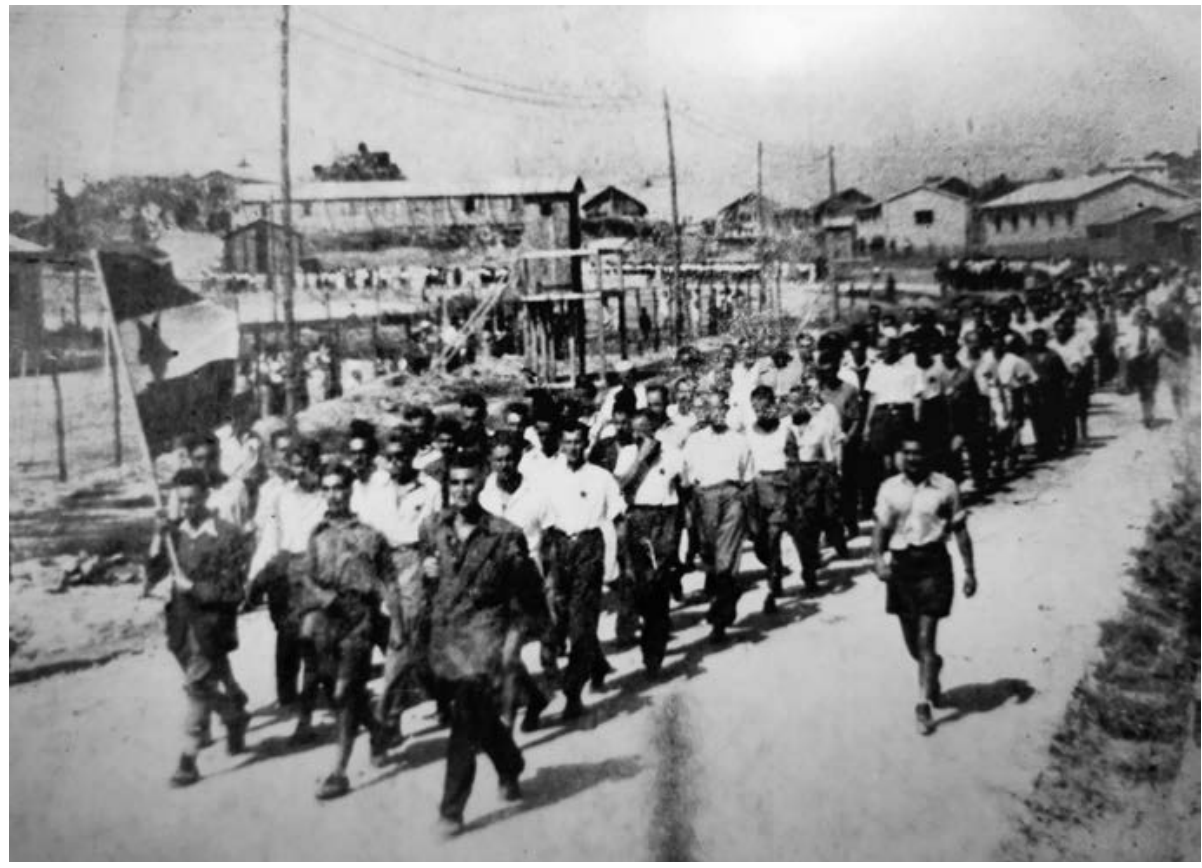

Figure 2. Jewish Fifth Batallion of the Rab Brigade on march, September 1943 (published by Jaša Romano in 1973). 
was also imposed on the "main collaborator" Ivan Mohar "for his crimes committed in the homeland and the evil he committed in the camp" (Jurančič, 1944: 23; Pakiž, 1953: 67; Potočnik, 1975: 232). Mohar was executed on the evening of September 15, 1943, by the Military Police unit of the OF (Potočnik, 1951: 53, 1953c: 153; Šušteršič, 1973: 553). Due to the "atmosphere of uncertainty," the sentence against Cujuli was to be carried out on September 18, 1943, but he committed suicide the night before the execution. He was buried, but exhumed on the instructions of the Executive Committee and transferred the same day to Rab, where he was buried "at the site of his heinous crimes." He was buried next to "his spy" Ivan Mohar, without a priest and in a coffin made of bare boards. Mohar was buried outside the cemetery, on the way to the graves, so that any visitor to this sad place could walk over and trample on them. The graves of Mohar and Cujuli, dug outside the cemetery walls, were meant to be a "small satisfaction" for the relatives of the victims of Cujuli's "bestial regime"14 (Jurančič, 1944: 23; Potočnik, 1948: 474, 1951: 54, 1953c: 163, 1975: 246-247; Konjhodžić, 1963: 554; Romano, 1973: 29; Šušteršič, 1973: 556; Vratuša, 1998: 217, 2009: 15).

\section{FORMATION OF THE RAB BRIGADE}

On the day after the disarmament of the Italian garrison on the Rab Island, September 12, 1943, recruitment for the Rab Brigade took place throughout the day; for this purpose, several recruiting commissions were active in Camp I with doctors from the Jewish camp. The formation of the brigade units, the supply of soldiers with linen, clothing, shoes, and weapons was carried out until September 15 (Potočnik, 1953c: 156, 1975: 228, 231). All the nurses in the Rab Brigade were Jewish women who had completed their nursing training in the concentration camp (Potočnik, 1953c: 162). In addition to the four battalions from the Slovenian part of the concentration camp, a Fifth Battalion of the Rab Brigade was formed in the Jewish camp. It consisted of three companies with three platoons each and a medical unit. The soldiers of the battalion were armed with rifles, and also had several machine guns. According to Jaša Romano, the battalion numbered 244 fighters (Romano, 1973: 28, 31, 1980: 282, 293). The Fifth Battalion represented the first Jewish combat unit of the Second World War. ${ }^{15}$

The Rab Brigade had its first combat engagement on the evening of September 13, when 120 of its soldiers went ashore on three motor-sailers at Cres Island. There, they surrounded

14 Or, as the former commander of the Rab Brigade wrote in the unequivocal language of postwar politics, "Today, the remains of this Fascist dog rot in a hole by the road to the Rab cemetery, crushed by the hand of the people who rose to fight Fascist tyranny" (Potočnik, 1953a: 9).

15 In Yad Vashem Memorial Park in Jerusalem, a memorial commemorates the "first Jewish military unit" formed in Britain in 1944. On my visit there, I pointed out to them the Jewish Fifth Battalion. Unfortunately, my report fell on deaf ears. 
the town of Osor, disarmed the Italian garrison and seized more weapons and ammunition. The landing on Cres was the largest maritime partisan operation in the Adriatic at that time (Potočnik, 1951: 51-53, 1953c: 156). The men of the Rab Brigade were sworn in on September 24, 1943, in Mašun on the mainland in a service held by priest Jože Lampret, curate of the XIV Division (Potočnik, 1975: 268). In a short speech on this occasion, he emphasized that the "liberation struggle of the Slovenian nation is most deeply and closely connected with the Christian principles of unity, freedom, and brotherly love" (ibid.: 270).

Before leaving the Rab Island, the former internees held a joint memorial service for those who had found their final resting place there. The funeral service took place among the fresh graves, where the choir sang Matej Bor's elegy To the Victims. Jože Jurančič then addressed the crowd. He was followed by Igo Gruden, who recited his poem written in the concentration camp Rab Island. Anton Vratuša then recalled the suffering in the concentration camp and the fallen friends they were saying goodbye to, and spoke of a brighter future. Recited were To the Victims (Vera Hreščak) and Karl Destovnik Kajuh's Through Rain and Storm (Drago Blanča), while the choir sang The Linden Green. At the end of the cultural program, Jurančič swore an oath on behalf of all the liberated internees, in memory of the fallen: "We swear to avenge this terrible crime, we swear never to forget your suffering." Once again To the Victims was sung, now by the Jewish choir. Leaving the cemetery, the crowd chanted in unison Hey, Slavs. ${ }^{16}$

\section{MEMORIAL CEMETERY ON THE ISLAND OF RAB}

The attitude of the Italian authorities towards the internees was one of rudeness and ruthlessness; they were all slavi, racially and culturally inferior people (Grazia, 2010: 12). ${ }^{17}$ Due to this attitude of the concentration camp authorities, the Rab internees lived in extremely unfavorable living, nutritional, and health conditions, which turned the concentration camp there into "a living tomb" in late 1942 and early 1943.

How many Rab internees remained on the island forever is still unclear. The chronicler of the monastery of St. Euphemia Odoriko Badurina noted that according to Italian official records, 1,267 people died in the camp, but all surviving records list fewer names. Two lists have been preserved in the archives of the Archdiocese of Ljubljana: the list of dead internees from Rab for the period from August 8, 1942, to May 20, 1943 lists 1,010 names, ${ }^{18}$ and the list of dead internees in Savoia Hospital in Fiume/Rijeka lists the names of 35 victims

\footnotetext{
16 Program spominske svečanosti na Kamporskem pokopališču. Archive of the Inštitut za novejšo zgodovino Ljubljana, collection Rab.

17 Giancarlo Grazia. 2010. Il campo della morte: l'isola di Arbe. Patria Indipendente, November 28: 12.

18 Elenco deceduti Campo concentramento internati civili di guerra Arbe (Fiume) August 8, 1942-May 20, 1943. Nadškofijski arhiv Ljubljana, folder Okupacija, box 2 .
} 
for the period from January 6 to August 5, 1943. ${ }^{19}$ Prior to the unveiling of the monument to the victims of the Rab concentration camp, Slovenski poročevalec published in February 1953 the list of 1,009 names of all victims known to the Committee for the Erection of a Monument to the Victims of the Rab Concentration Camp to the Main Committee of the Association of Combatants, asking relatives and acquaintances of those who would have perished on Rab for help, as the list was allegedly "very incomplete." ${ }^{20}$ However, no data on other victims was collected. But, at the beginning of January 1953, France Potočnik recorded 1,057 graves in the cemetery at Kampor Bay (Potočnik, 1953a: 9).

The cemetery in Kampor Bay on the island of Rab was after the liberation of the concentration camp left to the ravages of time. In 1950, the Main Committee of the Association of Combatants of the National Liberation Struggle in Ljubljana commissioned a student working group to clean and maintain the eventually "badly neglected" cemetery, so that visitors would not be "horrified by the disregard shown by Slovenians for the heritage of this camp, which still bears witness to the great sufferings of our people in their struggle for freedom." ${ }^{21}$ Two years later, the Main Committee decided to carry out a larger action. Namely, in the cemetery, they identified "the largest mass grave of Slovenians outside their closer homeland" and as such "a crying document of the atrocities committed by Italian Fascism ten years ago" (Potočnik, 1953a: 9; Vilfan, 1953: 5). They decided to pay their respects to the martyrs of the Rab concentration camp on the tenth anniversary of the liberation of the camp and the founding of the Rab Brigade by thoroughly cleaning their final resting place and erecting "a worthy monument" to them. The initiators of the action had no doubt that the ceremonial unveiling of the renovated cemetery would be a "powerful multinational event” (Potočnik, 1953a: 9).

The change in attitude toward the cemetery is probably due to international circumstances. In the early post-war years, Yugoslavia was under intense pressure from the West regarding the determination of its western border with Italy. The open question of the border resulted from the different positions of the two nations on the logic of its solution: The Italian side claimed the border as defined by the Rapallo Treaty in 1922, while Yugoslavia sought an ethnic demarcation. The peace treaty concluded in 1947 established the Free Territory of Trieste (FTT), divided into Zones A and B. The former included Trieste with its hinterland, the latter the present-day Slovenian coast and part of Croatia up to the mouth of the Mirna. When the Western Allies announced, without Yugoslavia's knowledge or consent, that Zone A would be placed under the Italian administration, the Yugoslav government put up fierce resistance. At mass protest rallies throughout the country, Yugoslav authorities worked to instrumentalize the grim memories of Italian occupation,

19 Elenco deceduti internati civili di guerra ospedale "Savoia « Fiume, 6. I. 1943-5. VIII. 1943. Nadškofijski arhiv Ljubljana, folder Okupacija, box 2 .

20 Žrtve italijanskega terorja na otoku Rabu. Slovenski poročevalec, February 1, 1953: 5.

21 J. J. 1950. Koncentracijsko taborišče na Rabu. Tovariš, August 3: 446. 


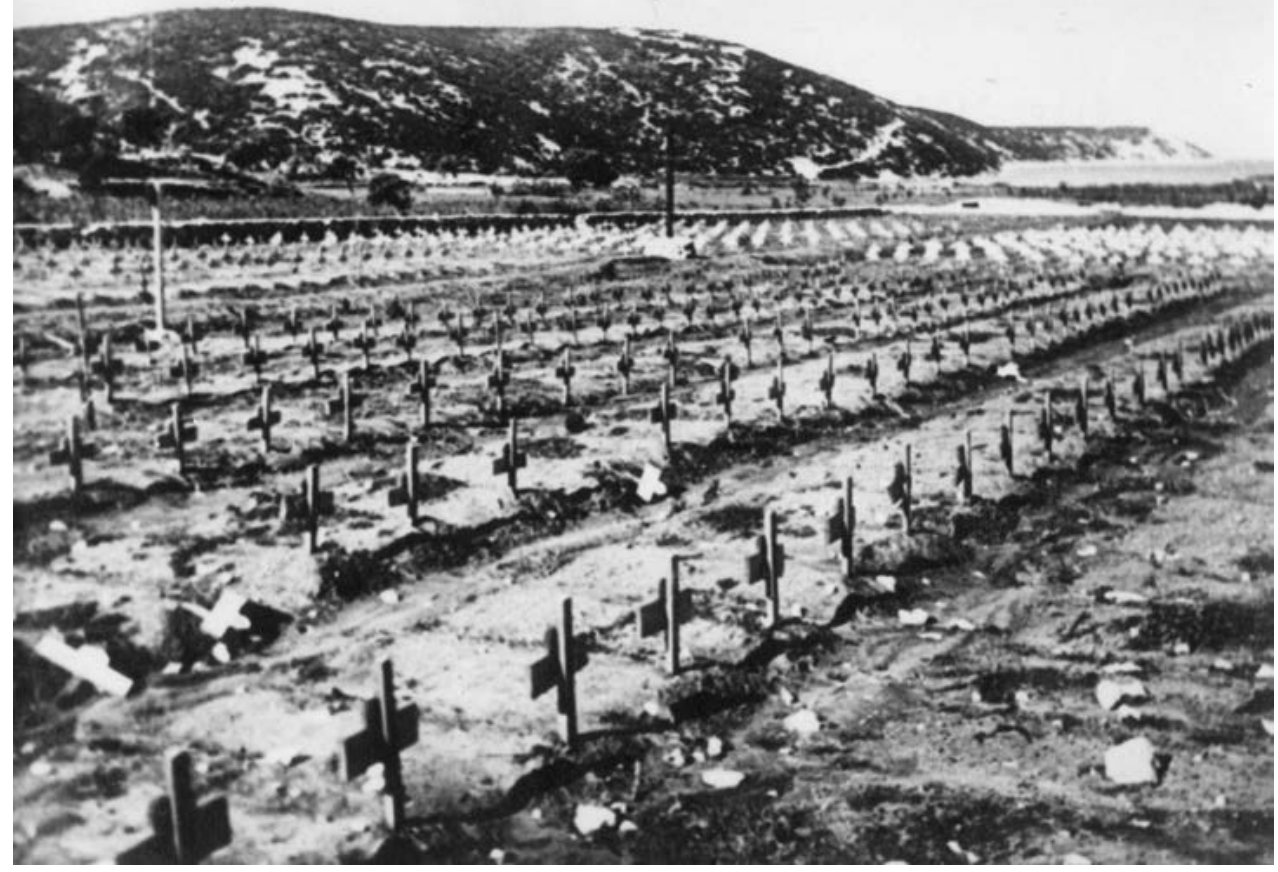

Figure 3. Cemetery for the inmates of the concentration camp Rab in 1943 (Archive of the National Museum of Contemporary History Ljubljana).

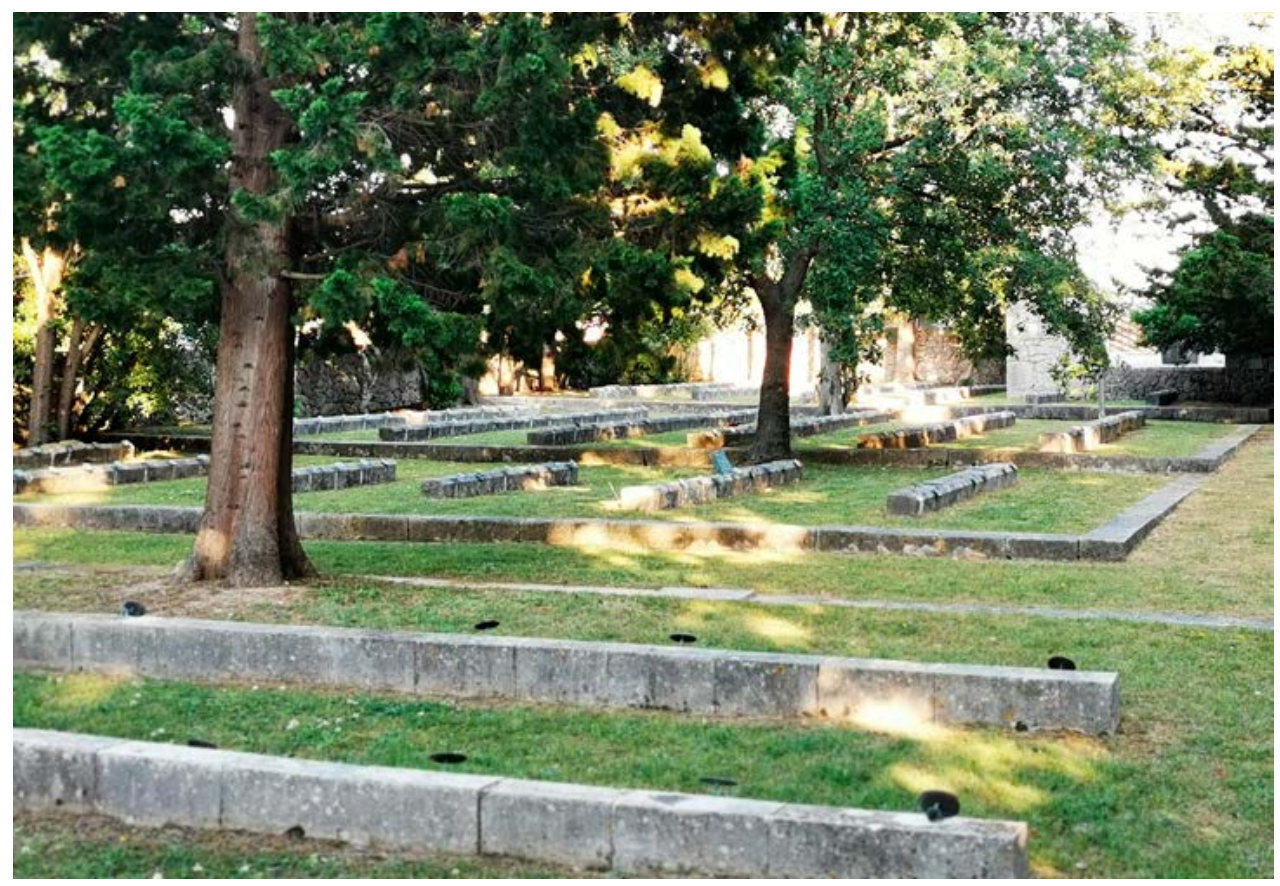

Figure 4. Memorial Complex Kampor today (photo by Božidar Jezernik). 
channeling them under the slogan “Trst je naš!” (“Trieste is ours!”) (Hoffman, Neal, 1962: 420; Čolaković, Janković, Morača, 1963: 501).

Yugoslavian authorities used the narrative about the Slovenian and Croatian victims of the brutal regime in the Rab concentration camp as a particularly effective weapon of anti-Italian propaganda. They did so not only out of sincere concern for the final resting place of the victims, but they used the tragic past as a kind of quarry from which to select "building material" that served their ideological and political goals. Thus, the Executive Council of the People's Republic of Slovenia classified the "Monument to the National Liberation War in Kampor on the island of Rab" as a monument of "greater national importance," and erected it with funds from the Republic of Slovenia (Ravnikar, 1954: 14).

\section{RENOVATION OF THE CEMETERY}

The Council for the Construction of the Monument on the Rab Island at the Main Committee of the Association of Combatants of the National Liberation Struggle in Ljubljana was founded at the end of 1952. Its members were former Rab inmates, among them some members of the OF Executive Committee in the Rab concentration camp. The Council was chaired personally by the commander of the former Rab Brigade, Franc Potočnik (see, e.g., Potočnik, 1953b: 1-2). Jože Jurančič was not involved: on April 4, 1949, he was arrested, despite his parliamentary immunity as a federal deputy. Until his mandate expired, he was imprisoned under a false name, while his family and acquaintances were informed that he had been shot in an unsuccessful attempt to flee across the border at Radgona. In 1952, he was transferred from the prison where he had been serving his sentence for "defecting the country" to Bileća Correctional Penitentiary, and from there the following year he was sent to Goli Otok. This fate was shared by three of his son Ilija from his first marriage, as well as his second wife Olga Virens-Jurančič, who refused to divorce him despite pressure from the Communist Party. ${ }^{22}$

As a bearer of the Commemorative Medal of the Partisans of 1941, a lieutenant colonel and a high functionary in rank (federal deputy, junior minister of education in Slovenia, etc.) Jože Jurančič was subjected to a particularly rigorous "re-education" upon his arrival in Bileća. Soon after he was assigned his bunk, he was called before the room elder, along with a sixteen-year-old boy with whom he paternally shared his supplies. "Look at this old scoundrel!" cried the elder. "It's such criminals and scoundrels who get children like you into trouble! It's all that old scoundrel's fault, that old bastard!" He asked the boy if he wanted to "atone." After answering in the affirmative, the boy was told to prove his loyalty by beating up "the old scoundrel." As he did not do this convincingly enough, they were both pushed against the wall while the room elder attacked Jurančič, expressing his vicious contempt

22 Virens-Jurančič, Olga. 1982. Personal Information. 
for "the bastards" (Mohor, 2007: 76). After the first few weeks of “re-education,” Jurančič was selected along with Martin, and Maks Stupica, for a special three-member task force called govprom (govno promet or "shit traffic"). From a deep concrete basin that collected fecal matter from all over Bileća Correctional Penitentiary, they scooped the slurry with a bucket and poured it into a barrel, passing it up and down the ladder among themselves. The man standing the lowest collected the slurry and handed it to the next who was higher up so that he could pass it to the third, who then poured it into the barrel. As a consequence, the workers' bodies and clothes were completely covered with feces (Mohor, 2007: 90).

The Council for the Construction of the Rab Monument at the Main Committee of the Association of Combatants of the National Liberation Struggle in Slovenia commissioned the architect Edvard Ravnikar to design and execute the works on the monument. The Council's commission travelled to Rab in the first days of January 1953 to assess the current state and carry out preliminary work. ${ }^{23}$ The original idea was to erect a monumental ossuary that would be "further emphasized by its dominant position" (Ravnikar, 1954: 14). A field inspection revealed that the task would be too extensive for the given period. Since the bodies were buried in clay soil, they were not yet fully decomposed, and there were also too many to rebury. A modified plan then proposed to build a solid wall around the cemetery and "thoroughly renovate" the camp, erect a small building next to it to house the memorial book, the gravedigger's tools, and a small museum, landscape the cemetery grounds, and erect a memorial with a large paved platform at its end. The architect proposed to divide the graves into several smaller plots, straighten them and lay marble slabs along the grave lines with the names of the victims engraved on bronze plaques. The individual grave plots were to be covered with grass and planted, so that in time the whole cemetery would become a grove. In addition, the cemetery paths should be paved, to serve as waterways as well. The site where Vincenzo Cujuli was buried should be properly marked, while the old site of the Italian searchlight should become a viewing point with a tall obelisk. The outlines of the former concentration camp should be marked with trees and plaques with short historical inscriptions. A similar plaque was to be placed by the road, at the point where the concentration camp site comes into view when exiting the town of Rab. It was also planned to restore part of the village cemetery with the first nineteen victims of the concentration camp and to embed a memorial plaque in the cemetery wall. ${ }^{24}$

The Council finally adopted the proposal of a monument in the form of a tidy cemetery, shaped and designed in such a way that all the elements are long-lasting and do not require special care. The elongated cemetery seems to flow into the sea and, as Venceslav Winkler writes, "when you look at it, your gaze goes straight to the homeland-at least in their final

23 Odbor za postavitev spomenika na Rabu. 1953. Poročilo o delu odbora. Glavnemu odboru Zveze borcev NOV, dne 20. februarja 1953, 1. Arhiv Slovenije, AS 1238, RO ZZB NOV Slovenije, box 376.

24 Odbor za postavitev spomenika na Rabu, 2; F. Š. 1953. Večno bo živel spomin na 4000 žrtev. Slovenski Jadran, April 24, 6; Ravnikar, Edvard. 1954. Spomenik NOB na Rabu. Arhitekt 11: 14-15, 14. 
resting place, the victims can see their home." ${ }^{25}$ The site was designed in horizontal planes so that rainstorms would no longer erode the ground and was given two architectural accents: an entrance platform and a covered space for the memorial book, two display cases, and a wall mosaic, the work of painter Marij Pregelj. It sums up the ideological rhetoric of the time. Various symbols of violence (burning houses, dead animals, gallows, the Fascist truncheon, and ax) and their opposites (five-pointed star, factory chimneys, Mount Triglav), represent the contrast between Fascism, war, and despair on the one hand, and Socialism, peace, and hope on the other. Against this background, the painter portrayed two emaciated male figures, one of them in chains, metaphors for the struggle of the dying prisoner, and the strength of the rebel who breaks the chains binding his wrists (Gabršek Prosenc, 1994: 30; Curtis, 2004: 29).

At the plenary session of the Council on January 25, 1953, it was decided that the unveiling would take place on the tenth anniversary of the liberation of the concentration camp Rab and the founding of the Rab Brigade. It was also decided to publish the Rab Almanack with documentary and literary content, to publish a complete list of camp victims according to the Italian records, and to supplement it with the names of those still unknown. In addition, the names of fighters and functionaries of the Rab Brigade and of those political activists who had not been honoured for their services, or who had been insufficiently honored, were collected so that they could receive appropriate decorations. ${ }^{26}$

\section{COMPANY OF THE ARMY POST 3234 BAKAR}

During its preliminary visit to the island of Rab, the Commission contacted a local construction company capable of carrying out earthworks and the construction of the cemetery walls, while deciding to entrust all works in stone "to the Army Postal Company 3234 Bakar, which has at its disposal all the necessary conditions and operates quarries on the islands of Goli Otok and St. Grgur." With an authorized representative of this company, the President of the Council for the Construction of the Rab Monument also agreed on January 17, 1953, that the "Quarry Service of the Army Postal Company 3234 Bakar" would be entrusted with the transportation of materials to the Rab Island, as well as masonry and engraving work. The company guaranteed to deliver all the required stones in time, to transport them to the island of Rab with its own means, and to assemble them with its own labor. ${ }^{27}$ The contract for the execution of the first phase of work of the cemetery in

25 Winkler, Venceslav. 1953. Plebiscit živih in mrtvih (13. septembra 1953 na Rabu). Tovariš, September 25: 1107.

26 Odbor za postavitev spomenika na Rabu, 3.

27 Ibid. 
Kampor Bay with the Army Postal Company 3234 Bakar was concluded on April 1, 1953, in Rijeka in the amount of 28,446.210 Yugoslav dinars. ${ }^{28}$

From the beginning of the operation of the Goli Otok concentration camp until 1953, the site on the island was officially named Radiliste Mermer ("Marble Worksite"), indicating that it was a stonemasonry operation, not a concentration camp for Cominform supporters. Eventually, the company Velebit was established in Rijeka to manage the quarry on Goli Otok Island; it also opened a showroom in the city for potential buyers (Mihailović, 1990: I, 346, 392). The company was under the management of the federal $\mathrm{UDBA}^{29}$ and, from 1949 to 1963, with special permission from the highest economic and political leaders, it engaged in illegal foreign trade to supply the Yugoslav Federation and the UDBA with foreign currency (Lukić, 1990: 260; Mihailović, 1990: I, 346-350; Previšić, 2019: 368). Their workers toiled hard and were compensated with three modest meals a day. UDBA, on the other hand, invested little but received plentiful. The agency sold products made by the forced labor of convicts on the Goli Otok at home and abroad, disregarding all regulations, and morals, and trading with Italians during the most heated period of the Trieste Crisis (Previšić, 2019: 367-368).

The main manufacturing industries of the Velebit Company were stone and wood processing. According to Vladimir Dedijer, the idea of Goli Otok as a space for the isolation of "Stalin's fifth column" was initiated by the sculptor Antun Augustinčić3 ${ }^{30}$ while searching for quality marble comparable to Carrara stone (Dedijer, 1984: 465). The years following the end of the Second World War were years of reconstruction and the creation of a new social order that promised a clean break with the past and the advent of a "new age." Essential to this process was the manifestation and manipulation of memory: the darker the past, the brighter the new vision of the future. The creation of a "new age" was likewise impossible without new heroes, whose important social task was to relegate the fallen heroes of the past deep into collective oblivion. An incalculable number of representations of the heroes of the "new age," cast in stone and bronze, filled the town squares all over Yugoslavia, marking countless places of remembrance of the "breaking" historical moments, so that as prophets-manifestos of the new truth-they would preserve the ideals of "brotherhood and unity," and the "common path to a glorious future."

28 Potočnik, 1953c. Vojna pošta 3234 Bakar; Arhiv Slovenije, AS 1238, RO ZZB NOV Slovenije, box 376.

29 Acronym for Uprava državne bezbednosti, i.e. the State Security Administration.

30 Augustinčić must have been inspired by the famous travelogue of Alberto Fortis, who in the late nineteenth century found on the Goli Otok Island "large quantities of white marble, suitable for sculpture, with a texture quite like that used by the ancient Romans, which was not, as is generally supposed, always Greek. Although this does not possess the snow-white whiteness which distinguishes Carrara marble, it seems often to have deceived both the sculptors and the judges of their works" (Fortis, 1774: II, 202-203). 
The product of Radilište Mermer did not exactly have the qualities attributed to it by Fortis, but this did not diminish its utility value in the "new age." For the "re-education" of the prisoners, it was enough that they were made to carry the rock from one pile to another and to break it with stones instead of hammers. However, since the UDBA was interested not only in the "re-education" of the prisoners but also in raising capital, the prisoners were forced to make various useful items. In 1953, they started mass production of floor tiles, with which almost all public and private buildings in Yugoslavia were paved, as the Goli Otok site was the only tile producer in the country for a long time. They also produced objects such as tables, chairs, ashtrays, vases, night lamps with shades made from a single piece of red and white marble, and the like (Mihailović, 1990: I, 347-348; Bobinac, 2017: 137). Stonework also included making pedestals for statues of national heroes and fallen fighters of the National Liberation War, ${ }^{31}$ "who probably would have risen from their graves if they had known this." 32

As we have already noted, the prisoners on the Goli Otok also did all the stonework for the construction of the monument to the victims of the Rab concentration camp. It was particularly problematic that among the forced laborers there were also former internees of the same concentration camp. ${ }^{33}$ Incidentally, among the forced laborers who carried out the finishing work on the Memorial Complex on the island of Rab, we find none other than Jože Jurančič. Thus, the teacher Jurančič, the internee from Goli Otok, erected a monument on the neighboring island of Rab to himself and the historical events in which he was the leader in September $1942 .{ }^{34}$ His tragedy was aptly described by Slavoj Žižek: First, he heroically overthrew the ancient régime in the Socialist Revolution, and ten years later, enslaved to the new rules, he was forced into oblivion by erecting a monument to his own communist past (Žižek, 2006: 288). Moreover, Jurančičs name did not appear at the commemoration of the tenth anniversary of the liberation of Rab and the founding of the Rab Brigade, nor in any of the many articles published in the Slovenian press to

31 Stone for similar purposes was also worked by prisoners in Bileća. This gave rise to the anecdote about life "playing tricks," told by Dragan Marković. A group of prisoners, including the "returning offender" Duško Vučinić, made the base of the monument to the national heroes near Trebinje. When Duško sat down to catch his breath, he got hit by the rifle of a policeman, who barked, "Don't shirk, you motherfucker!" to which Vučinić replied that he is cursing the mother of a national hero. He calmly informed the angry officer that the statue being erected represented his eldest brother National Hero Vlado Vučinić and his fallen comrades from the town (Marković, 1987: 102).

32 Marić, Milomir. 1988. Na magarcu u svetsku revoluciju. Duga, October 20: 94-97, 96.

33 Jurančič, Jože. 1982. Personal information; Logar, Cene. 1991. Goli otok. Borec 4-5-6: 265-335, 308; Žižić, Bogdan. 2011. Gorući grm. Alfred Pal-život i djelo, 127-128. Zagreb: Durieux; Zvonar Predan, ibid., 14.

34 Drčar-Murko, Mojca. 1996. Vsako etnično čiščenje zahteva demonizacijo žrtev. (Intervju z Božidarjem Jezernikom). Delo: Sobotna priloga, October 26: 39; Ivelja, Ranka. 2013. Intervju. Dnevnik: Objektiv, July 6: 8-10, 8; Zvonar Predan, Darka. 2015. Po osvoboditvi so izgubili še grobove. Večer: V Soboto, May 9: 12-15, 14 . 
mark the occasion. One even looks in vain for his name in the Rab Almanack, ${ }^{35}$ although there is a comprehensive article by France Drenovec describing the formation and activity of the Liberation Front during the internment (Drenovec, 1953), as well as an article on the military organization of the internees contributed by Franc Potočnik (1953c). In his memoirs published two years earlier, the latter addresses Jurančič simply as "our president" (Potočnik, 1951: 50).

An ominous omission that speaks volumes about the fact that both the Council for the Construction of the Rab Monument and its President knew exactly where Jože Jurančič was at that time. It is also clear that this fact did not make them particularly uncomfortable, not in their dealings with "Army Postal Company 3234 Bakar," nor at the commemoration ceremony on September 12-13, 1953, when they gloriously commemorated all those who had rendered outstanding services to the liberation of the concentration camp and the town of Rab.

\section{THE SOCIAL FRAMEWORK OF REMEMBRANCE AND CATHARSIS}

On the occasion of the tenth anniversary of the liberation of the concentration camp and the disarmament of the Italian military occupation, a magnificent commemoration was held on the island on Saturday and Sunday, September 12 and 13, 1953. The commemoration was tied to the celebrations of the tenth anniversary of the liberation of the town of Rab, which had been liberated by former Slovenian and Croatian internees. ${ }^{36}$ The celebrations attracted thousands of visitors from Slovenia, Gorski Kotor, the Northern Littoral, Pag, and other nearby islands to the island of Rab, ${ }^{37}$ and were attended by many high representatives of Slovenia and Croatia. ${ }^{38}$

The central part of the memorial service took place on Sunday, September 13, 1953, in the renovated cemetery for the Rab internees. Thousands of participants gathered in front of the tribune with the inscription that Italian crimes will not be forgotten. ${ }^{39}$ Speakers mainly evoked memories of the time of the Fascist government and placed these memories

35 In the contemporary Slovenian press, the Rab Almanack was advertised as a book "containing many documents which constitute grave testimony to the sadism and bloodthirstiness of the Italian occupation" (see, e.g., Od 14.000 internirancev jih je v rabskem peklu umrlo 5000; Primorski dnevnik, September 12, 1953: 1.

36 F. D. 1953a. Pred jutrišnjo svečanostjo na Rabu. Slovenski poročevalec, September 12: 2.

37 Drnovec, France. 1953. Množice Slovencev - Rab obtožuje. Slovenski poročevalec, September 13: 1; F. D. 1953b: 1; B. K. 1953. Pretresljiva svečanost na Rabu. Slovenski Poročevalec, September 14: 1.

38 Rabski grobovi obtožujejo - Rab-priča »kulturnega poslanstva« italijanskih imperialističnih zavojevalcev. Primorski dnevnik, September 15, 1953: 1, 3; Naši narodi ne morejo pozabiti na strahote italijanskih zločinov. Ljudska pravica - Borba, September 14, 1953: 1.; B. K., ibid.

39 B. K., ibid.; Winkler, Venceslav. 1953. Plebiscit živih in mrtvih (13. septembra 1953 na Rabu). Tovariš, September 25: 1107. 
in the context of current tensions at the border with Italy. In this context, the renovated cemetery of Slovenian and Croatian internees served as a great backdrop to stimulate an emotional response to the current conflict on the country's western border. This is how all the speeches were intoned. Marko Belinić, a member of the Executive Council of the Republic of Croatia, was the first speaker. In a short speech, he stated that the ceremony was "dedicated to the Slovenian and Croat victims who fought heroically against Fascism and died on this field." ${ }^{40} \mathrm{He}$ added that "the monument in the cemetery will forever indict the Italian fascist oppressors." ${ }^{11}$

After him, the former commandant of the Rab Brigade described the horrors of the concentration camp there. Franc Potočnik emphasized that Rab held a special place among all concentration camps because it was intended for the "complete extermination of Slovenians." According to Potočnik, the Italian aggressors sent half-naked and barefoot people of all sexes and ages, including underage children, to the Rab "death camp," where "5,000 internees died in terrible agony and suffering." ${ }^{\prime 2} \mathrm{He}$ stressed that this was "by no means an exaggeration, but a historical fact to which this huge cemetery bears witness." ${ }^{\prime 3}$ In his speech, he then revived in detail the memory of the resistance movement of the Slovenian internees in the Rab concentration camp. He referred to January 5, 1943, as the turning point in Camp I, when the Executive Committee of the Liberation Front was founded, "the central leadership of all Rab internees." ${ }^{34}$ He described the development of the organization of the Liberation Front among the internees and the formation of illegal military units, with the help of which the internees liberated first the concentration camp and then the town of Rab. Finally, he recalled a memorial service that former internees held at the same place exactly ten years before, on September 13, 1943, to bid farewell to their dead comrades before the Rab Brigade "began its triumphal march towards final victory." ${ }^{\prime 35}$ In his long speech, he found no place to mention Jože Jurančič’s name. But he did not forget to update the events at the end. He emphasized that the "death camp" of Rab was not only "a document of the eternal shame of the Italian conquerors, but also a proof of the extraordinary vitality, the willingness to sacrifice, and the fighting spirit of our people, who were guided by the ideas of the Communist Party, the Liberation Front, and the National Liberation Struggle." ${ }^{\prime 6}$

40 B. K., ibid.

41 Rabski grobovi obtožujejo - Rab-priča »kulturnega poslanstva» italijanskih imperialističnih zavojevalcev, ibid.

42 Ibid.

43 B. K., ibid.

${ }_{44}$ Naši narodi ne morejo pozabiti na strahote italijanskih zločinov. Ljudska pravica - Borba, September 14, 1953: 1 .

45 B. K., ibid.

46 Ibid. 
Other speakers also stressed that the cemetery was a reminder to all those who threatened the Yugoslav western border and wanted to conquer Yugoslav territory, "for which every Yugoslav is ready to fight to the last breath." ${ }^{\prime 4}$

The restored cemetery of Slovenian and Croatian victims of Italian Fascism was thus intended not only to preserve a pious memory, but to be a "pillar of shame of Italian culture and 'heroism' on our soil"; the " 5,000 graves" there were to bear witness forever to the "cultural mission" of Italian imperialism. ${ }^{48}$ With a newly built cemetery with " 5,000 graves" for the victims of the Rab concentration camp, they wanted to permanently denounce the crimes of Italian imperialism during the Second World War and at the same time give their children and their children's children a clear warning to "defend the homeland to the last drop of blood" in the event of an enemy attack, and to beware of "two-thousand-year-old Roman cultures" like of a "scabby dog."

After his speech, the Secretary General of the Central Committee of the Yugoslav Combatants' Association, National Hero Želimir Stojnić, opened the solemnly decorated "cemetery of Slovenian and Croatian internees, victims of the crimes of Italian rule on our soil." ${ }^{50}$ The relatives of the Rab victims then shook the earth from their homes into a large stone ember. The entrance to the cemetery was opened to the sounds of funeral marches. Official delegations laid wreaths and the crowd thronged among the graves, looking for the names of deceased relatives on copper plaques. There was probably no one among them who had not brought a wreath or a bouquet from home. The startled cries of those who found copper plaques with the names of their relatives and lit candles before them rang out from all sides. ${ }^{51}$ Reporters described moving scenes as some women dressed in black wept for their deceased partners and children, some even "weeping and digging into the earth as if to embrace one last time their husbands, sons, and daughters, resting there in the soil of Rab." 52

47 Rabski grobovi obtožujejo - Rab-priča »kulturnega poslanstva« italijanskih imperialističnih zavojevalcev, 1; Naši narodi ne morejo pozabiti na strahote italijanskih zločinov, 1; Spominske svečanosti na Rabu. Slovenski Jadran, September 18, 1953: 3.

48 Rabski grobovi obtožujejo - Rab-priča »kulturnega poslanstva« italijanskih imperialističnih zavojevalcev, 1; Drenovec, ibid.

49 F. Š., ibid. See also F. D. 1953b. Množice iz Slovenije so se včeraj poklonile na grobovih rabskih žrtev. Slovenski Poročevalec, September 13: 1; Rabski grobovi obtožujejo - Rab-priča "kulturnega poslanstva" italijanskih imperialističnih zavojevalcev. Primorski dnevnik, September 15, 1953: 1, 3; Winkler, ibid.; B. K., ibid.

50 Drenovec, ibid.; Na otoku Rabu je bilo odkrito na novo urejeno grobišče žrtev italijanskega fašizma. Posavski tednik, September 19, 1953: 1.

51 B. K. ibid.; Winkler, ibid.; F. D. 1953b: 1; Od 14.000 internirancev jih je v rabskem peklu umrlo 5000. Primorski dnevnik, September 12, 1953: 1; Nepodpisano. 1953d. Rabski grobovi obtožujejo Rab-priča »kulturnega poslanstva«italijanskih imperialističnih zavojevalcev, 1; Na otoku Rabu je bilo odkrito na novo urejeno grobišče žrtev italijanskega fašizma. Posavski tednik, September 19, 1953: 1.

52 Of the 14,000 internees, 5,000 died in the hell of Rab. 


\section{COMING TO TERMS WITH THE TERRIBLE PAST}

After the liberation of the camp in September 1943, of the whole Rab concentration camp only in the "Fifth Sector" there were no major changes, ${ }^{53}$ even after some relatives exhumed the remains of their deceased relatives in the post-war years (Vratuša, 1998: 97). When the teacher Etbin Bojc, a former internee from Rab, visited the cemetery with a school from Domžale in 1950, he was still able to find graves with the names of some of his former fellow internees among the "countless named and unnamed graves" (Bojc, 1974: 192). In the early 1950s, it also happened at the cemetery that a landowner "simply laid out a field over the graves" (Potočnik, 1953b: 1).

According to the oft-quoted description of the "Fifth Sector" by Silverij Pakiž, after a decade of its existence, the Rab internees' cemetery was "an opaque row of dark gray earthen graves, with low wooden crosses and no greenery, a real field of corpses, very miserable and without an artificial increase of misery, like the bitter and sad life of the victims in the Rab camp" (Pakiž, 1953: 62). This gloomy image changed only in 1953, when the cemetery was dressed for the solemn occasion "in all the splendour and glory that only respect and love can bestow." ${ }^{4}$ For this occasion, the architect Edvard Ravnikar, on the initiative of the Association of Combatants of the National Liberation War of Slovenia, with the participation of the entire business community, and the entire population of the Republic of Slovenia, and with the support of the Slovenian and Croatian Executive Councils, built "a magnificent memorial cemetery, in memory of the dead and as a reminder to the living" (Vratuša, 1998: 106).

The mobilization of society to defend the state's borders has relegated reverence for the deceased to collective oblivion. The Memorial Complex built on the site of the former cemetery no longer preserves the original individual graves that the Italian camp authorities had assigned to their victims. With only the aesthetic and propaganda mobilization effect before his eyes, the architect had somehow obscured the ethical aspect of the project. Ravnikar and his collaborators created a beautifully laid-out necropolis with 1056 marked individual graves, ${ }^{55}$ but they failed to place the stone blocks with plaques bearing the names of the victims where they were actually buried. At first glance, the elongated arrangement of the stones with tablets gives the Memorial Complex the "impression of a space without a third dimension" (Barić, 2018: 20), which undoubtedly contributes to the aesthetic effect of the whole. However, the scenic appearance hides the fact that the mortal remains of not a single person whose name appears on the name plaque lie in the indicated place. The tragic consequence of the complete subordination of ethical norms to the aesthetic and propagandistic effect of the newly designed Memorial Complex is the

\footnotetext{
53 J. J., ibid.; Kozinc, Željko. 1966. Pozaba, ki boli in žali. Tovariš, November 3: 10-13.

54 J. J. 1953. Ob deseti obletnici osvoboditve taborišča na Rabu. Dolenjski list, September 4: 5.

55 Kralj, Drago. 1965. Pozaba, ki boli in žali. Tovariš, November 5: 14-17.
} 
situation in which the victims of Fascist violence have lost what even the concentration camp authorities granted them: their graves. ${ }^{56}$

\section{METAMORPHOSIS OF MEMORY}

Today, commemorations are being held at the memorial complex in Kampor Bay on the weekend closest to September 11. On these occasions, representatives of the Croatian and Slovenian authorities, municipalities, associations of veterans of the anti-fascist struggle, and associations of surviving internees, as well as the public, lay wreaths and light candles.

The most resounding commemoration took place on September 5, 2020, when the President of the Republic of Slovenia Borut Pahor and the President of the Republic of Croatia Zoran Milanović attended a commemoration marking the anniversary of the liberation of the former Italian concentration camp on the island of Rab. The two Presidents laid a wreath at the monument to the victims of "Italian Fascist terror." After the ceremony, the two presidents visited a photo-documentary exhibition entitled The Last Witnesses-Memories of the Internees in the Italian Fascist Camps. As the Slovenian president tweeted on the occasion, the fact that both Presidents attended the commemoration together for the first time "symbolizes the importance of friendship and mutual awareness of the need to preserve memory, which should also be a reminder." In its report on this event, Primorski dnevnik recalled that "until then, the memorial park in Kampor, which is the work of the famous Slovenian architect Edvard Ravnikar, has not been visited by any official representative of Italy." It expressed hope that the joint "pious step of Milanović and Pahor, which also has a political symbolic charge," will encourage Rome to send at least the Italian ambassador to Zagreb to pay homage to the victims of Italian violence and apologize for their suffering." ${ }^{7}$

The cultural-historical importance of the Memorial Complex in Kampor Bay was emphasized by the curators of the Slovenian contribution to the 9th International Architecture Exhibition in Venice in 2004. In doing so, they wanted to re-establish Edvard Ravnikar as one of the great masters of architecture in the second half of the twentieth century. A complementary exhibition entitled The Metamorphosis OfMemory: The Memorial Cemetery On The Island Of Rab (1953) By Edvard Ravnikar was shown in the same year at the National Gallery in Ljubljana. The curators of the exhibition introduced the architect Ravnikar as the author of the modern city centers of Ljubljana and Kranj, as an urban planner for Nova Gorica, and also as the designer of the Memorial Complex on the island of Rab, which is "perhaps his most lyrical work, devoted to the eternal architecture that was created as a poetic reminder of the World War II atrocities” (Demšar, Hrausky, 2004: 12).

56 Zvonar Predan, ibid.: 14; Dežman, Jože. 2018. Komunistični ateistični pokop (KAP) in skrunjenje posmrtnih ostankov. Časnik, January 31; see also Kosovel, 2015: 47; Dežman, 2021: 57.

57 Tence, Sandor. 2020. Kdaj na Rabu uradni predstavnik Italije. Primorski dnevnik, September 9: 4. 
On Rab, Ravnikar used the traditional Mediterranean town as a model, with gates to the land and the sea, the main corso, and a square. The Memorial Complex, built in 1953, was thus conceived as a city in which the dead could "live on." According to the interpretation of the authors of the Slovenian contribution to the 2004 Venice exhibition, the cemeteries in this city of the dead function as an urban fabric that complements the monumental structure. They also emphasized that the Memorial Complex, although laid out in the time of the "un-religious socialist system," still has "all the elements of a Christian necropolis": Visitors to the memorial site follow the via sacra with smaller monuments to the center, marked by an obelisk "that replaces the bell tower," followed by a crypt with sarcophagi and a mosaic. "There are not many places," they pointed out, "that express the whole in such a direct and convincing way - present, future, past and eternity, the four time dimensions given to man, sealed together in a single place” (Dešman, Hrausky, 2004: 14).

By transforming objects from history, retaining some past meanings and rejecting others, the builder of the Memorial Complex altered the past for motives that suited the needs of daily politics. The past thereby transformed corresponded more to the self-images and aspirations of current political leaders than to the tragic fate of the victims of the Rab concentration camp. When built, the Memorial Complex on the island of Rab did not serve to preserve the memory of the individual victims but to help visitors come to terms with the multitude of the dead and to develop a negative attitude towards fascism in general. On this basis, the Memorial Complex served to mobilize visitors emotionally around the agenda of their political leaders. In their focus on these issues, they all overlooked the question of the rights of concentration camp victims, who remained on the island of Rab only because they were Slovenians or Croats, to their individual graves. However, this question was not raised at any of the annual commemorations, nor by the authors of the exhibition on the aesthetic achievements of Edvard Ravnikar in 2004.

Since its inauguration in 1953, the City of the Dead in Kampor Bay and its aesthetic aspect, combined with the important issues of political relations between the three bordering nation-states and the coexistence of their peoples, have cast an ever-increasing shadow over the tragic victims of the concentration camp. Under this shadow, the victims were irretrievably deprived of their individual graves, and the political leadership paradoxically transformed the memorial site into a place of the nameless dead, that is, a place of oblivion, through solemn commemorations.

\section{REFERENCES}

Badurina, Odoriko. 1942/43. Kronika samostana u Kamporu: Vol. V. Archive of the Franjevačka biblioteka Kampor-Rab.

Barić, Ivo. 2018. Spomenički kompleks Edvarda Ravnikara na Rabu. Rab: Udruga antifašista Raba.

Beretič. Miran. 1985. Krvava žetev. Dolenjski list, October 3: 19. 
Bobinac, Vladimir. 2017. Informbiroovac: Uspomene iz Titova Alcatraza. Zagreb: Naklada Pavičić.

Bojc, Etbin. 1974. Internirani na Rabu (Pred 30 leti). Zbornik občine Grosuplje 6: 181-192.

Curtis, William J. R. 2004. Odmišljanje in prikazovanje. In Arhitekt Edvard Ravnikar, spominski kompleks na otoku Rab, 1953 / Architect Edvard Ravnikar, Memorial Complex on the Island of Rab, 1953, eds. Miha Dešman and Andrej Hrausky, 17-36. Ljubljana: DESSA.

Čolaković, Rodoljub, Dragoslav Janković, and Pero Morača, eds. 1963. Pregled istorije Saveza komunista Jugoslavije. Beograd: Institut za izučavanje radničkog pokreta.

Dedijer, Vladimir. 1984. Novi prilozi za biografiju Josipa Broza Tita: Vol. 3. Beograd: Rad.

Dešman, Miha, and Andrej Hrausky, eds. 2004. Arhitekt Edvard Ravnikar, spominski kompleks na otoku Rab, 1953 / Architect Edvard Ravnikar, Memorial Complex on the Island of Rab. Ljubljana: DESSA.

Dežman, Jože, ed. 2021. Pravica do groba: 5. poročilo Komisije Vlade RS za reševanje vprašanj prikritih grobišč. Ljubljana: Družina.

Drenovec, Francè. 1953. Osvobodilna fronta v rabskem taborišču. Rabski zbornik, 113-132. Ljubljana: Glavni odbor Zveze borcev NOV Slovenije.

Fortis, Alberto. 1774. Viaggio in Dalmazia. Venezia: Alvise Milocco.

Gabršek Prosenc, Meta. 1994. Edvard Ravnikar. Piranesi 2: 28-31.

Granda, Stane. 2007. Zgodovina Šmarjete in Bele Cerkve. In Šmarjeta in Bela Cerkev skozi stoletja: Vršenje časa okrog zgodovinskega Vinjega vrha v občini Šmarješke Toplice, eds. France Cvelbar and Stane Granda, 51-217. Šmarjeta, Novo mesto: Domoznansko društvo, Založba Goga.

Hoffman, George W., and Fred Warner Neal. 1962. Yugoslavia and the New Communism. New York: Twentieth Century Fund.

Jezernik, Božidar. 1999. Struggle for Survival: Italian Concentration Camps for Slovenes during the Second World War. Ljubljana: Društvo za preučevanje zgodovine, literature in antropologije.

Jurančič, Josip. 1930. Iz šole za narod. Ljubljana: Slovenska šolska matica.

Jurančič, Jože. 1944. Epilog. S. Matejev (= Silverij Pakiž). In Rab, 46-51. Partizanska tiskarna.

Jurančič, Jože. 1985. Politično življenje in delo v taborišču. In Pričevanja rabskih internirancev (1942-1943), ed. Herman Janež, 95-102. Ljubljana: ČZP Kmečki glas.

Konjhodžić, Mahmud. 1963. Od Kupe do mora. Zagreb: Epoha.

Kosovel, Blaž. 2015. Pozabljeni predhodnik Nove Gorice: Nekočje tam stalo pokopališče Razpotja 22: 47-48.

Kužatko, Želimir. 2010. Otok Sveti Grgur hrvatski Gulag. Zagreb: Počasni bleiburški vod.

Lowenthal, David. 1985. The Past Is a Foreign Country. Cambridge: Cambridge University Press.

Lukić, Vojin. 1990. Brionski plenum: Obračun sa Aleksandrom Rankovićem - sećanja i saznanja. Beograd: Stručna knjiga.

Malnar, Slavko. 2003. Predgovor. In Patnje u fašističkim logorima Italije 1942.-1943, ed. Ivan Malnar, 5-10. Rijeka, Čabar: Adamić, Ogranak Matice hrvatske.

Marković, Dragoslav. 1987. Istina o Golom otoku. Beograd, Ljubljana: Narodna knjiga, Partizanska knjiga.

Mihailović, Dragoslav. 1990. Goli otok: Vol. 1. Beograd: Beogradski izdavačko-grafički zavod.

Mohor - Ston, Bogdan. 2007. Luna: Od koroškega partizana do političnega zapornika v Bileči. Celovec: Drava.

Nikolić, Kosta. 1994. Boljševizacija KPJ 1919-1929: Istorijskeposledice. Beograd: Institut za savremenu istoriju. 
Pakiž, Silverij. 1953. Internacijsko taborišče na otoku Rabu in interniranci v njem. In Rabskizbornik, 13-74. Ljubljana: Glavni odbor Zveze borcev NOV Slovenije.

Potočnik, Franc. 1946. Rab. Ljudska pravica, April 27: 14.

Potočnik, France. 1948. Eno leto Raba; Tovariš, May 14: 473-474.

Potočnik, Franc. 1951. Žice, morje in gozdovi. Ljubljana: Slovenski knjižni zavod.

Potočnik, France. 1953a. Na Rabu. Slovenski poročevalec, January 18: 9.

Potočnik, Franc. 1953b. Zastupniku „Odbora za postavitev spomenika na Rabu“ drugu Vinku Bakota, z dne 9. 3. 1953; Arhiv Slovenije, AS 1238, RO ZZB NOV Slovenije, box 376.

Potočnik, Franc. 1953c. Vojaška organizacija internirancev v taborišču na otoku Rabu. In Rabski zbornik, 145-163. Ljubljana: Glavni odbor Zveze borcev NOV Slovenije.

Potočnik, Franc. 1975. Koncentracijsko taborišče Rab. Koper: Založba Lipa.

Previšić, Martin. 2019. Povijest Golog otoka. Zaprešić: Fraktura.

Ravnikar, Edvard. 1954. Spomenik NOB na Rabu. Arhitekt (11): 14-15.

Romano, Jaša. 1973. Jevreji u logoru na Rabu i njihovo uključivanje u Narodnooslobodilački rat. Jevrejski istorijski muzej: Zbornik 2: 1-72.

Romano, Jaša. 1980. Jevreji Jugoslavije 1941-1945: Žrtve genocida i učesnici narodnooslobodilačkog rata. Beograd: Savez jevrejskih opština Jugoslavije.

Škufca, Jože. 1998. Jože Jurančič (1902-1998). Dolenjski list, November 26: 17.

Smole, Barica. 2002. Telški bog: Življenje in delo učitelja Jožeta Jurančiča. Rast 1:36-43.

Strmčnik, France. 1999. Pedagoške zgode in nezgode z Goličave (intervju z Jožetom Jurančičem). Šolska kronika 2: 348-352.

Šušteršič, France. 1973. Rab 1943. Borec 10: 540-556.

Vratuša, Anton. 1998. Iz verigv svobodo - Rabska brigada. Ljubljana: Društvo piscev zgodovine NOB Slovenije.

Walston, James. 1997. History and Memory of the Italian Concentration Camps. Historical Journal 40 (1): 169-183. DOI: https://doi.org/10.1017/S0018246X96007042.

Žižek, Slavoj. 2006. The Parallax View. Cambridge: The MIT Press. DOI: https://doi.org/10.7551/ mitpress/5231.001.0001.

\section{PREOBLIKOVANJE DEDIŠČINE ITALIJANSKEGA KONCENTRACIJSKEGA TABORIŠČA NA OTOKU RABU}

Leta 1942 je italijanska okupacijsk oblast v t. i. Ljubljanski provinci zaradi "pomiritve" uvedla ostre represivne ukrepe, med njimi tudi množično interniranje civilnega prebivalstva. Po podatkih iz uradnih dokumentov italijanske vlade s konca oktobra 1942 je bilo tedaj v petih koncentracijskih taboriščih (Gonars, Padova, Treviso, Rab in Renicci) »kakih 20.000 slovenskih civilnih internirancev". Največje taborišč je bilo na otoku Rabu, kjer je bilo sredi decembra 1942 interniranih kar 10.552 ljudi obeh spolov in vseh starosti. Življenjske razmere 
$v$ tem koncentracijskem taborišču so bile v splošnem precej slabše kot drugod, posledica pa je bila izredno visoka umrljivost v novembru in decembru 1942.

Med interniranci v koncentracijskem taborišč na Rabu je bil tudi nekdanji učitelj in član Komunistične partije Jože Jurančič, ki je ohranil zavest "dolžnosti" tudi v težkih razmerah, kakršne so bile tam konec leta 1942. Med množico izmučenih in nezaupljivih neznancev je iskal posamične komuniste in je že septembra 1942 z njihovo pomočjo ustanovil tajni komite Komunistične partije in postal njegov sekretar. Čeprav so bili deli taborǐ̌ča na Rabu ločeni z bodečo žico in zastraženi, se je komitejema v slovenskem in judovskem delu taborišča posrečilo najti stik in sodelovanje. Zaradi boljšega usklajevanja dela in organiziranosti med Osvobodilno fronto $v$ slovenskem delu koncentracijskega taborišca in Komitejem za nacionalno osvoboditev $v$ judovskem, so ustanovili skupni Izvršni odbor OF; njegov sekretar je postal Jože Jurančič, njegov najtesnejsi sodelavec pa Viktor Hajon iz judovskega dela taborišča.

11. septembra 1943 so se italijanski vojaki in karabinjerji začeli pomikati proti mestu Rab, da bi se tam vkrcali na ladje. Na njihovi poti proti pristanišču so jih prestregle enote nekdanjih internirancev in jim nekaj z zvijačo in nekaj s silo zaplenile orožje. Nato so razorožili še tiste, ki so že bili vkrcani na ladjah. Tako je bila razorožena celotna italijanska posadka na otoku, ki je stela kakih 2200 izurjenih vojakov in karabinjerjev, ne da bi bil sprožen en sam strel. Italijanske vojake je razorožilo kakih 2000 nekdanjih internirancev, ki so bili pred tem skoraj brez vsakršnega strelnega orožja, kar je dogodek brez primerjave v svetovnem merilu. Veličastnost tega dogodka še povečuje dejstvo, da nekdanji interniranci niso likvidirali nobenega italijanskega vojaka ali karabinjerja. Da do tega ni prišlo, je zasluga Izvršnega odbora OF, ki je odločno preprečilo vsakršno samovoljno maščevanje, in to kljub družinski tragediji sekretarja Izvršnega odbora OF; njegova žena Leopoldina je bila namreč konec meseca septembra 1942 ustreljena kot prva talka na Dolenjskem.

Dan po razorožitvi italijanske posadke so nekdanji interniranci ustanovili Rabsko brigado. Štela je štiri bataljone, oblikovane v slovenskem delu koncentracijskega taborišča, medtem ko so v judovskem delu ustanovili Peti bataljon Rabske brigade, ki je bil prva judovska oborožena vojaška enota, nastala med 2. svetovno vojno. Rabska brigada je izvedla prvo oboroženo akcijo 13. septembra 1943, ko je razorožila še italijansko posadko na otoku Cres. Akcija na Cresu je bila največja pomorska vojaška akcija v tistem času.

Preden so nekdanji interniranci, organizirani $v$ Rabsko brigado, zapustili otok Rab, so se na spominski slovesnosti poslovili od več kot tisoč svojih nekdanjih sointernirancev, ki so za zmeraj ostali na otoku. Pokojne so namreč pokopavali na posebnem pokopališcu v zalivu Kampor. Grobovi na njem so bili urejeni v dolge vrste s križi, na katerih so bila imena pokojnikov, sredi pokopališča je bil visok križ. Po osvoboditvi taborišča in mesta Rab je bilo pokopališče prepuščeno zobu časa. Prenovili so ga po načrtu arhitekta Edvarda Ravnikarja šele ob 10. letnici osvoboditve leta 1953, na vrhuncu napetosti med Jugoslavijo in Italijo zaradi nerazrešenega vprašanja meje med državama. Odbor za ureditev spominskega kompleksa v zalivu Kampor je za delavce najel internirance iz takratnega koncentracijskega taborišca na Golem otoku. Pri tem je bilo še posebej tragično, da so bili med njimi tudi taki kakor Jože Jurančič, ki so bili prej internirani na Rabu. 
Tako so tako rekoč postavljali spomenik sami sebi. Prenovljeno pokopališre je bilo slovesno odprto ob navzočnosti visokih zastopnikov oblasti in več tisoč obiskovalcev iz Slovenije in Hrvaške, med njimi so bili tudi številni svojci rabskih žrtev, ki so grobove želeli okrasiti s cvetjem in svečami. Dejansko pa tega niso mogli storiti, ker je bilo pokopališce prenovljeno tako, da pod nobenim označenim grobom ne ležijo posmrtni ostanki pokojnika, katerega ime je napisano na njem.

Prof. Dr. Božidar Jezernik, University of Ljubljana, Faculty of Arts, bozidar.jezernik@ff.uni-lj.si 